\title{
Foregrounding the Complexities of a Dialogic Approach to Global International Relations
}

Deepshikha Shahi

University of Delhi

\begin{abstract}
The ever more global character of today's International Relations (IR) is no longer satisfied with one-sided stories about how things have gone with either the West or the non-West. Rather, the ongoing discussions on Global IR persuade both the West and the non-West to squarely unfold their own narratives. As the theories and practices of contemporary international relations have remarkably acquired a 'Global' impetus, a lot of premium is being put on a 'dialogic approach'-that is, an approach to Global IR that insists upon a deeper two-way communicativeaction between the West and the non-West. Although the dialogic approach to Global IR seeks to resolve a wide range of cognitive differences between the West and the non-West, it more often than not remains thwarted by a few unsettled contestations: (i) History vs. Philosophy, (ii) Chronology vs. Covariance, (iii) Language vs. Concept, (iv) Culture vs. Economy, and (v) Single vs. Plural. This paper sets out to shed light on these unsettled contestations in an endeavour to intellectually improve the prospects of a dialogic approach to Global IR.
\end{abstract}

Keywords: Global IR, Eurocentrism, Dialogue, Western IR, non-Western IR

Descriptions of the state of the art in international relations usually oscillate between the diagnosis of an impoverished present and visions of a better future based on dialogue...If dialogue is so highly appreciated, why is there so much monologue?

\section{Introduction}

In a bid to transcend the barriers of an impoverished present and to carve a better future, the theories and practices of contemporary international relations (IR) have strikingly acquired a 'Global' impetus. The intensifying discussions on Global IR seek to dilute the already problematized 'Eurocentric' nature of IR knowledge ${ }^{2}$ - which is built upon the misconception that Western history and Western political theory are world history and world political theory - by placing it into a non-Western, or broader, Global, context. ${ }^{3}$ Against this backdrop, a lot

Deepshikha Shahi, Assistant Professor of Political Science, University of Delhi. Email: deepshikha.shahi@gmail.com (D) 00000002-5027-0872

${ }^{1}$ Gunther Hellmann, "Are Dialogue and Synthesis Possible in International Relations?," International Studies Review 5, no. 1 (2003): 123.

2 John M. Hobson, The Eastern Origins of Western Civilisation (Cambridge: Cambridge University Press, 2004); Branwen G. Jones, ed., Decolonizing International Relations (Lanham: Rowman \& Littlefield, 2006); Siba N. Grovogui, Beyond Eurocentrism and Anarchy: Memories of International Order and Institutions (New York, NY: Palgrave Macmillan, 2006); Turan Kayaoglu, "Westphalian Eurocentrism in International Relations Theory," International Studies Review 12, no. 2 (2010): 193-217; Brian C. Schmidt, "A Realist View of the Eurocentric Conception of World Politics," Millennium:Journal of International Studies 42, no. 2 (2014): 464-71; Zeynep G. Capan, "Decolonising International Relations?," Third World Quarterly 38, no. 1 (2017): 1-15.

${ }^{3}$ Amitav Acharya and Barry Buzan, The Making of Global International Relations (Cambridge: Cambridge University Press, 2019). 
of premium is being put on a 'dialogic' approach to Global IR - that is, an intellectual strategy that emphasizes deeper dialogues, two-way communications, and ideational-exchanges between the West and the non-West. ${ }^{4}$ Although the dialogic approach to Global IR aspires to 'reconcile' a wide range of cognitive differences between the West and the non-West, it more often than not remains thwarted by a few unsettled contestations: (i) History vs. Philosophy, (ii) Chronology vs. Covariance, (iii) Language vs. Concept, (iv) Culture vs. Economy, and (v) Single vs. Plural. This paper intends to not only scrutinize the disruptive nature of these unsettled contestations - which tend to trim down ongoing dialogic drills into disjointed monologues - but also detect possible pathways to improve the prospects of a dialogic approach to Global IR. The paper is divided into three sections. The first section illustrates the conceptual evolution of 'dialogue' in Eurocentric IR. The second section articulates how the contextual shift of 'dialogue' from Eurocentric IR to Global IR is still problematic: in fact, the potential of a dialogic approach to Global IR remains somewhat under-exploited due to the failure to recognize some frequently encountered hurdles that systematically undermine West-non-West interactions. Finally, the third section suggests some measures to facilitate an effective West-non-West dialogue that could probably strengthen a conscientious pursuit of Global IR.

\section{2. 'Dialogue' in Eurocentric IR: State-of-the-art}

How did the idea of dialogue evolve over time in Eurocentric IR? At the very outset, it is imperative to acknowledge that the term 'dialogue' in IR encompasses a plurality of meanings. Deriving from the Greek concept of dia-logos ('meaning-through'), the myriad implications of dialogue in IR - as collaborative-meaning-making-ventures ${ }^{5}$ - have come a long way from Thucydides' 'dialectical argumentation' (as expressed in the Melian dialogue), ${ }^{6}$ to Habermasian 'rational-discourse for strategic-bargaining' and 'communicative-action for consent-seeking', ${ }^{7}$ to Bakhtinian 'avoiding of the two extremes of monologue and war', and 'description of the human condition' or 'mode for being-in-the-world', 8 to 'awareness of the always absent "other" that evades the enclosure acts in conversations', 9 to 'interaction between different methodological backgrounds', ${ }^{10}$ to 'ability to change the regulative idea of science' 11 and 'recombine analytic components of competing theories'; 12 to 'engaged pluralism as a

${ }^{4}$ Meera Sabaratnam, "IR in Dialogue. But Can We Change the Subjects? ATypology of Decolonising Strategies for the Study of World Politics," Millennium: Journal of International Studies 39, no. 3 (2011): 781-803; Guy Harpaz, "The Role of Dialogue in Reflecting and Constituting International Relations: The Causes and Consequences of a Deficient European-Israeli Dialogue," Review of International Studies 37, no. 4 (2011): 1857-883; John M. Hobson and Alina Sajed, "Navigating Beyond the Eurofetishist Frontier of Critical IR Theory: Exploring the Complex Landscapes of Non-Western Agency," International Studies Review 19, no. 4 (2017): 547-72.

5 David Bohm, On Dialogue (London: Routledge, 1996).

${ }^{6}$ Hayward R. Alker, “The Dialectical Logic of Thucydides' Melian Dialogue,” The American Political Science Review 82, no. 3 (1988): 805-20.

7 Iver B. Neumann, "International Relations as Emergent Bakhtinian Dialogue," International Studies Review 5, no. 1 (2003): 137-40; Harald Muller, "Arguing, Bargainig and All That: Communicative Action, Rationalist Theory and the Logic of Appropriateness in International Relations," European Journal of International Relations 10, no. 3 (2004): 395 - 435; Thomas Diez and Jill Steans, "A Useful Dialogue? Habermas and International Relations," Review of International Studies 31 (2005): 127-40.

${ }^{8}$ Neumann, "International Relations"; Xavier Guillaume, "Bakhtin: From Substance to Process," in International Relations Theory and Philosophy: Interpretive Dialogues, ed. C. Moore and C. Farrands (London and New York: Routledge, 2010).

9 James Der Derian, Critical Practices in International Theory: Selected Essays (London and New York: Routledge, 2009).

${ }_{10}$ Detlef F. Sprinz and Yael Wolinsky-Nahmias, Cases, Numbers, Models: International Relations Research Methods (Michigan: University of Michigan Press, 2002); Judith A. Tickner, "Dealing with Difference: Problems and Possibilities for Dialogue in International Relations," Millennium: Journal of International Studies 39, no. 3 (2013): 607-18.

${ }^{11}$ Friedrich Kratochwil, The Puzzles of Politics: Inquiries into the Genesis and Transformation of International Relations (New York: Routledge, 2010).

${ }^{12}$ Rudra Sil and Peter Katzenstein, "Analytic Eclecticism in the Study of World Politics: Reconfiguring Problems and Mecha- 
potential remedy to long-enduring knowledge-problems, ${ }^{13}$ and to the discipline's capacity to share knowledge through 'cross-paradigmatic or inter-epistemic synthesis' based upon an 'endless journey through time and space that, given the unpredictable circumstances we encounter along the way, forces us to adapt on the spot over and over again'. ${ }^{14}$

Retrospectively speaking, most of these implications of dialogue developed as corollaries to the 'great debates' in IR. While Thucydides' Melian dialogue came to be associated with the first great debate (or 'idealist-realist debate'), ${ }^{15}$ 'dialogue as methodological interaction' developed into an extension of the incomplete second great debate (or 'history-science debate'). ${ }^{16}$ Likewise, 'dialogue as engaged pluralism' carried forward the unfinished business of the third great debate (or 'interparadigmatic debate'), ${ }^{17}$ and 'dialogue as inter-epistemic synthesis' advanced as an investigation of the fourth great debate (or 'positivist-postpositivist debate'). ${ }^{18}$ Although it is persuasively argued that the 'great debates' are the most established means of telling the disciplinary history of IR (or, for that matter, the conceptual progression of 'dialogue' in IR), ${ }^{19}$ a few IR scholars have begun to interrogate not only the utility of 'great debates', ${ }^{20}$ but also the lack of differentiation between 'dialogue' and other forms of human communication such as 'debate'. ${ }^{21}$ In fact, some IR scholars have rightly questioned the dominant tendency among present-day IR scholars to prefer 'debate' over 'dialogue', and 'pluralism' over 'synthesis'. ${ }^{22}$

Noticeably, the varied insinuations of dialogue - which remain interior to the margins of 'great debates' - suffer from a habitual Eurocentric bias: for instance, James N. Rosenau conceives a Eurocentric notion of 'global dialogues' which omits the Third World as one of the unavoidable major perspectives, ${ }^{23}$ and Andrew Linklater imagines a Eurocentric existence of 'dialogic communities' which displays an inside-out-prejudice by attributing the West's development of higher levels of rationalization and morality to its own unique ability to learn and borrow from other non-Western cultures. ${ }^{24}$ Under these circumstances, it is no

nisms across Research Traditions," Perspectives on Politics 8, no. 2 (2010): 411-31.

${ }^{13}$ Yosef Lapid, "Through Dialogue to Engaged Pluralism: The Unfinished Business of the Third Debate," International Studies Review 5, no. 1 (2003): 128-31.

14 Hellmann, "Are Dialogue and Synthesis Possible," 149

15 Włodzimierz J. Korab-Karpowicz, "How International Relations Theorists Can Benefit by Reading Thucydides," The Monist 89, no. 2 (2006): $232-44$.

16 Simon Curtis and Marjo Koivisto, "Towards a Second 'Second Debate'? Rethinking the Relationship between Science and History in International Theory," International Relations 24, no. 4 (2010): 433-55.

${ }^{17}$ Lapid, "Through Dialogue".

18 Andrew Moravcsik, "Theory Synthesis in International Relations: Real Not Metaphysical," International Studies Review 5, no. 1 (2003): 131-36.

19 Ole Wæver, "The Sociology of a Not so International Discipline," International Organization 52, no. 4 (1998): $687-727$.

20 Hartmut Behr and Michael C. Williams observe: 'The history of the discipline of International Relations [as it proceeds through the 'great debates'] is usually narrated as a succession of theories that would pursue different ontologies and epistemologies and focus on different problems. This narrative provides some structure to a multifaceted field and its diverse discussions. However, it is also highly problematic as it ignores common problems, intersections and mutual inspirations and overemphasizes divides over eventual commonalities. Rather than such overemphasis, we suggest instead negotiating between 'IR theories' and elaborating their shared foci and philosophies of science in order to provide new perspectives on and approaches to international politics'. Hartmut Behr and Michael C. Williams, “Interlocuting Classical Realism and Critical Theory: Negotiating 'Divides' in International Relations Theory," Journal of International Political Theory 13, no. 1 (2017): 3.

${ }^{21}$ Lapid, "Through Dialogue".

22 Hellmann, "Are Dialogue and Synthesis Possible".

23 James N. Rosenau, Global Voices: Dialogues in International Relations (Boulder: Westview Press, 1993); Albert J. Paolini, Navigating Modernity: Postcolonialism, Identity, and International Relations (London: Lynne Rienner Publishers, 1999$), 138$.

${ }^{24}$ This problem of 'inside-out-prejudice' which is frequently encountered during global dialogues is what John M. Hobson and Alina Sajed call 'Eurofetishism' whereby, all too often, the non-West is considered as distinct from the West such that a completely 'relational' conception of the West - one in which the non-West shapes, tracks, and inflects the West as much as vice versa - is either downplayed or dismissed altogether, thereby missing 'global interconnectivities'. Hobson and Sajed, "Navigating Beyond the Eurofetishist Frontier". Andrew Linklater, "The Changing Contours of Critical International Relations Theory," in Critical Theory and World Politics, ed. Richard Wyn Jones (London: Lynne Reinner Publishers, 2001); Alexander Anievas, “On Habermas, Marx and the 
wonder that several IR scholars across the world (in both West and non-West) have started to call for an expansion in the scope of dialogue by moving it exterior to the margins of 'great debates'. It is assumed that a truly Global interdiscipline of international studies - which is free from parochialisms of different sorts (geographical, linguistic, methodological, and political) - is achievable via dialogue between not only 'subfields and specializations', but also 'West and non-West'. ${ }^{25}$ While the dialogue between West and non-West aims to grant the academic discipline of IR a Global (read non-Eurocentric) character, it is undeniable that the performance of dialogue in the context of Global IR is also not hassle-free.

\title{
3. 'Dialogue' in Global IR: Persisting Puzzles
}

So, what are the enduring dilemmas of dialogue under the ambit of Global IR? From a Global (or say, non-Eurocentric) standpoint, the likelihood of dialogue subsists on numerous platforms - such as 'inter-civilizational', 'inter-cultural', 'inter-religious' (or 'interfaith'), 'inter-regional' and so on. ${ }^{26}$ Since all these platforms - which stimulate different trajectories for West-non-West dialogues - are invariably significant, it is convincingly proposed that Global IR is not limited to a single global dialogue. Amitav Acharya and Barry Buzan assert: ${ }^{27}$

\begin{abstract}
Global IR is not limited to a single global dialogue as some mistakenly interpret our position... Global IR does not expect that IR community should engage in a single global conversation about theory or method...what matters for Global IR is not how many conversations [about how many theories and methods] are going on, but who is excluded from each of these... [In fact], Global IR cannot resolve, nor is it primarily concerned with, interparadigmatic and 'isms' debate in IR...Global IR calls more for synthesis than for choosing one approach over the others.
\end{abstract}

But then, how would 'West-non-West synthesis' become practicable if multiple global dialogues in Global IR fail to encourage non-Western narratives to at least 'speak to' (if not resolve) the prearranged 'isms' debate foundational to Western IR? One way out can be traced in those non-Western approaches that show a willingness to 'speak to' the 'isms' debate (and the associated perceptions of 'objectivities'/'subjectivities') in Western IR, albeit on calculated terms and conditions of retaining the 'West-non-West cognitive gap' (read 'parentheses'). Walter D. Mignolo comments: ${ }^{28}$

Inter-cultural dialogue, or inter-epistemic dialogue between epistemologies, based on the
premise of objectivity without parantheses, could prove deadly when agencies defending
opposite objectivities [or scientificities] without parentheses confront each other. Dialogue

Critical Theory Tradition: Theoretical Mastery or Drift?," in International Relations Theory and Philosophy: Interpretive Dialogues, ed. C. Moore and C. Farrands. (London: Routledge, 2010), 153.

${ }_{25}$ Thomas J. Biersteker, "Eroding Boundaries, Contested Terrain," International Studies Review 1 (1999): 3-9; Margaret G. Hermann, "One Field, Many Perspectives: Building the Foundations for Dialogue," International Studies Quarterly 42 (1998): 605-24; John M. Hobson, "East and West in Global History," Theory, Culture \& Society 23, no. 2-3 (2006): 408-10; Gurminder K. Bhambra, "Talking Among Themselves? Weberian and Marxist Historical Sociologies as Dialogues Without 'Others'," Millennium: Journal of International Studies 39, no. 3 (2011): 667-81; Amitav Acharya, "Dialogue and Discovery: In Search of International Relations Theories Beyond the West," Millennium: Journal of International Studies 39, no. 3 (2011): 619-37.

${ }^{26}$ Hans Köchler and Gudrun Grabher, eds., Civilizations - Conflict or Dialogue? (Vienna: International Progress Organization, 1999); Helle Malmvig, "Security through Intercultural Dialogue? Implications of the Securitization of Euro-Mediterranean Dialogue between Cultures," Mediterranean Politics 10, no. 3 (2005): 349-64; Thomas Banchoff, "Religion and the Global Politics of Human Dignity," in Human Dignity and the Future of Global Institutions, ed. Mark P. Lagon and Anthony Clark Arend (Georgetown: Georgetown University Press, 2014), 257-76; Peter M. Kristensen, "International relations in China and Europe: The Case for Interregional Dialogue in a Hegemonic Discipline," The Pacific Review 28, no. 2 (2014): 161-87.

${ }^{27}$ Acharya and Buzan, The Making of Global International Relations, 299.

${ }^{28}$ Walter D. Mignolo, The Darker Side of Western Modernity: Global Futures, Decolonial Options (Durham and London: Duke 
becomes unsustainable. ${ }^{29}$ Objectivity in parentheses, on the other hand, opens up the doors for true inter-epistemic (and intercultural) dialogues.

While 'objectivity in parentheses' keeps the choice of multiple global dialogues open, its near-compulsory preoccupation with the 'West-non-West binary' quite reasonably raises a few eyebrows. Kimberly Hutchings warns: ${ }^{30}$

There is a politics to the West/non-West distinction that is bound up with predominant models for dialogue in IR; rethinking these models of dialogue implies a new politics, and therefore also, I will suggest, a move away from the West/non-West binary as a way of characterising the participants in dialogic exchange oriented towards the expansive transformation of disciplinary imaginaries.

Most certainly, a dialogic exchange oriented towards the expansive transformation of disciplinary imaginaries demands a move beyond colonial/post-colonial/de-colonial binaries of 'all-powerful West vs. powerless non-West', or, for that matter, 'non-Western silence vs. non-Western defiance'. ${ }^{31}$ To be sure, the binary style of global dialogues - situated upon 'subject-object dualism/s' - remain ever-ready to invent and include new 'subjectpositions' ${ }^{32}$ However, scholarly competition among these 'subject-positions' - which claim to unleash multiple binary styles of global dialogues - leads to a greater or lesser degree of 'sameness'. Kamila Pieczara explains: ${ }^{33}$

Some resemblances of dialogue are based upon pressures produced by competition, which through selection lead to sameness. Like in Waltz, competition produces a tendency toward sameness of the competitors...It is because of competition, spurring imitation, and ultimately leading to sameness that makes for - in the words of Thomas Biersteker [2009] - 'intellectual reproduction' in the field...Although [many] non-Western scholars see the reality of their regions differently, they [more often than not] strive to squeeze their observations into existing ['dualist' Western] IR frameworks [that promote 'binaries'].

And even if the non-Western scholars do not strive to squeeze their observations into dualist Western IR frameworks, their observations are still interpreted through customary binaries: for example, the non-Western expressions such as China's tribute system, guanxi or tianxia are recounted using the customary Westphalian binaries wherein 'China' directly connotes the People's Republic of China, rather than seeing the method as a holist governing system of the world. ${ }^{34}$ Thus, by design, the binary style of global dialogue/s reinforces dualist Western IR frameworks and, in so doing, inclines toward 'solidifying existing stereotypes' and 'fuelling narcissistic turf war'. ${ }^{35}$ Alternatively, the non-binary style of global dialogue/s

${ }^{29}$ Echoing a similar sentiment, Arlene B. Tickner and David L. Blaney proclaim: 'Neopositivism not only occupies the throne of science [or objectivity], granting it the power of the 'god trick'... but also its followers cannot help but try and convert others [i.e. 'non-believers'] into believers from this elevated position. In consequence, a pluralist science [or objectivity] of IR...would entail either inviting non-believers to the table...or subsuming scholarship done by those who share a vaguely similar wager (such as in the global South) as inferior or 'substandard'... a dialogue between distinctive perspectives or wagers... may be nearly impossible to sustain in practice given the current structure of global intellectual production'. Arlene B. Tickner and David L. Blaney, Claiming the International (New York: Routledge, 2013), 2.

${ }^{30}$ Kimberly Hutchings, "Dialogue between Whom? The Role of the West/ Non-West Distinction in Promoting Global Dialogue in IR," Millennium: Journal of International Studies 39, no. 3 (2011): 639.

${ }^{31}$ Hobson and Sajed, "Navigating Beyond the Eurofetishist Frontier".

${ }^{32}$ Sabaratnam, "IR in Dialogue".

${ }^{33}$ Kamila Pieczara, "Two Modes of Dialogue in IR : Testing on Western versus Non-Western Engagement with IR Theory," Millennium Annual Conference, London School of Economics (2010): 5-6.

${ }^{34}$ Kosuke Shimizu, "The Genealogy of Culturalist International Relations in Japan and Its Implications for Post-Western Discourse," All Azimuth 7, no. 1 (2018): 121-36.

${ }^{35}$ Agnes Tuna, "Intercultural Dialogue: Only a Means, Not an End in Itself. New-Med Research Network," 2016, https://www. osce.org/networks/newmedtrackII/292946?download=true; Yong-Soo Eun, "Beyond 'the West/non-West Divide' in IR: How to En- 
- which sometimes speaks back to the West, and at other times occurs for reasons 'Otherwise'- plans to avoid undesirable self-perpetuating divisive labelling mechanism that accentuates (not synthesizes or reconciles) disciplinary boundaries. ${ }^{36}$ Indeed, it is this nonbinary-style of global dialogue/s - for instance, the one that hunts for a reconciliation of 'Eurocentric dualism' with a few up-and-coming models of 'non-Eurocentric monism' that suitably stands to leverage a conscientious pursuit of Global IR. ${ }^{37} \mathrm{But}$ then, it is crucial to recall that the non-binary style of global dialogue/s too faces some problems. The next section methodically foregrounds these often unidentified problems that regularly obstruct an effective West-non-West dialogue.

\section{Toward an Effective West-non-West Dialogue: A Conscientious Pursuit of Global IR}

The problems that hinder an effective West-non-West dialogue (including non-binary style of global dialogue/s) are mostly rooted in a few unsettled contestations: (i) History vs. Philosophy, (ii) Chronology vs. Covariance, (iii) Language vs. Concept, (iv) Culture vs. Economy, and (v) Single vs. Plural. Since it is held that the 'problem functions as its own solution', in what follows, an attempt has been made to expose each of these unsettled contestations, so that the problems inherent in them could, then, work as their own solution. ${ }^{38}$

\subsection{History vs. philosophy}

Lately, the non-Western parts of the globe have contributed several IR theories that emanate from their ancient/medieval/modern 'philosophical heritage': for instance, Tianxia ('allunder-heaven') from China; Advaita ('non-duality') from India; Basso Ostinato ('recurrent underlying motif') from Japan; Ubuntu ('collective personhood') from Africa; Dhikr, Takrar and Tawil ('repetition, lack of repetition, and interpretation') from Turkey etc. ${ }^{39}$ However, whenever a non-Western philosophical heritage is activated to comprehend contemporary realities of IR, its capabilities are more often than not restrictively evaluated on the basis of its 'historical limits': that is to say, a philosophical heritage is considered fertile only to the extent that it succeeds within the temporal-spatial boundaries of its origin. As such,

sure Dialogue as Mutual Learning," The Chinese Journal of International Politics 11, no. 4 (2018): $435-49$.

${ }^{36}$ Hobson and Sajed, "Navigating Beyond the Eurofetishist Frontier"; Cora Lacatus, Daniel Schade, and Yuan Yao, "Quo vadis IR: Method, Methodology and Innovation," Millennium: Journal of International Studies 43, no. 3 (2015): 767-78.

37 It is important to admit that Eurocentric IR necessarily thrives upon dualist theoretical frameworks. Yet, one cannot put forward an indefensible claim that 'the West' is inherently 'dualist' or 'the non-West' is innately 'monist' (or 'non-dualist'). In fact, there has been a persistent presence of philosophical dualism and monism in both the Western and Eastern parts of the world. To be sure, a few Western scholars have diligently disclosed the ambiguities of 'subject-object-dualism'. For instance, Arthur O. Lovejoy clarifies that no content, whether of perception or thought, is totally 'subjective': therefore, whenever dualists argue that the immediate data of perception or memory are subjective, they cannot mean that the immediate data of perception or memory are 'in the subject'. Likewise, Brand Blanshard opines that any acceptable demarcating lines between subject and object, or subject and the world, could only be located in the field of consciousness. While Bernard Williams reveals the problems of the self as a 'subject', Derek Parfit pinpoints that the 'subject' of experiences is not a 'person' or 'Cartesian Ego'. However, none of these non-dualist lines of thinking have been consistently employed to develop a full-grown theory of world politics in Eurocentric IR. Deepshikha Shahi, Advaita as a Global International Relations Theory (London and New York: Routledge, 2018); Arthur O. Lovejoy, The Revolt Against Dualism (Chicago: Open Ccourt Publishing, 1930); Brand Blanshard, The Nature of Thought (2 volumes) (London: George Allen and Unwin Ltd, 1939); Bernard Williams, Problems of the Self: Philosophical Papers 1956-1972 (Cambridge: Cambridge University Press, 1973); Derek Parfit, Reasons and Persons (Oxford: Oxford University Press, 1984).

38 Slavoj Žižek, "The Most Sublime of Hysterics: Hegel with Lacan,” 2006, http://www.lacan.com/zizlacan2.htm.

${ }^{39}$ Zhao Tingyang, "Rethinking Empire from a Chinese Concept 'All-under-Heaven'," Social Identities 12, no. 1 (2006): 29-41; Shahi, Advaita; Felix Rösch and Atsuko Watanabe, "Approaching the Unsynthesizable in International Politics: Giving Substance to Security Discourses through Basso Ostinato?,” European Journal of International Relations 23, no. 3 (2016): 609-29; Thomas K. Tieku, "Collectivist Worldview: Its Challenge to International Relations," in Africa and International Relations in the Twenty-First Century, ed. Fantu Cheru, Timothy Shaw, and Scarlett Cornelissen (Basingstoke: Palgrave Macmillan, 2012); Ali Balci, "Knowledge, Repetition and Power in Ibn al-'Arabi's Thought: Some Preliminary Comments on Methodology," All Azimuth 4, no. 1 (2015): 39-50. 
history is mobilized as a tool to truncate philosophy. Nevertheless, the historical readings of a philosophy have their own limits: supposedly, if a philosophy works at a particular temporalspatial point (i.e. historical juncture), it does not mean that it would work forever ${ }^{40}$; likewise, if a philosophy does not work at a particular temporal-spatial point, it does not mean that it would not work ever. Hence, whenever 'History vs. Philosophy' dispute crops up to distort an effective West-non-West dialogue, the question that one needs to ask is this: why should we accept 'history' (or records of the past) as a natural limit to human future potential?

\subsection{Chronology vs. covariance}

Since 'history' normally acts as a guide to examine the present, it inadvertently gives birth to another perplexity - namely, the perplexity pertaining to 'chronological battle' over who came first in (re)producing a particular idea/concept/method/theory. An example of this chronological battle can be found in confrontations over the actual 'pioneer of realpolitik' in IR: because the realpolitik of Kautilya's Arthaśāstra (2-4 $4^{\text {th }}$ century CE) appeared much before the realpolitik of Machiavelli's The Prince (1532), it is considered appropriate to label Machiavelli as 'Italian or Mediterranean Kautilya', not Kautilya as 'Indian Machiavelli'. ${ }^{41}$ However, such a chronological battle is unfruitful in terms of its ability to support a Westnon-West dialogue: although it revitalizes the status of Kautilya's Arthaśāstra as a potent non-Western device to attack the Eurocentric roots of contemporary IR, it encourages a narrow re-reading of the extra-ordinarily comprehensive 'eclectic philosophical foundation' of this classical text which neatly goes beyond Machiavelli's The Prince. ${ }^{42}$ Clearly, such a chronological battle demonstrates how 'competition produces a tendency toward sameness of the competitors'. ${ }^{43}$ Besides, it occasionally creates a flawed impression that a particular $\mathrm{idea} / \mathrm{concept} / \mathrm{method} /$ theory has to always historically travel from one place to another before showing up at both the places. In fact, whenever a chronological battle tries to circumscribe a West-non-West dialogue, one can start to rethink through Helmuth Plessner's concept of 'covariance': since the concept of 'covariance assumes that intrinsically (or genetically) related ideas can be generated in historically and culturally distant spaces' ${ }^{4}$ anybody located at any temporal-spatial point could concentrate and capture the freely floating ideas which are provincially neither Western nor non-Western. So, instead of 'provincializing', an effective West-non-West dialogue must insist upon the task of 'non-provincializing' a particular idea/ concept/method/theory.

40 In fact, the dominant theoretical frameworks in Eurocentric IR - guided by diverse philosophies of realism, liberalism and constructivism - have been commonly stumped by 'change', thereby indicating that none of these philosophies could work forever. Jack Snyder $(2004,61)$ writes: 'Realists failed to predict the end of the Cold War, for example. Even after it happened, they tended to assume that the new system would become multipolar ("back to the future", as the scholar John J. Mearsheimer put it). Likewise, the liberal theory of democratic peace is stronger on what happens after states become democratic than in predicting the timing of democratic transitions, let alone prescribing how to make transitions happen peacefully. Constructivists are good at describing changes in norms and ideas, but they are weak on the material and institutional circumstances necessary to support the emergence of consensus about new values and ideas. With such uncertain guidance from the theoretical realm, it is no wonder that policymakers, activists, and public commentators fall prey to simplistic or wishful thinking about how to effect change'. Jack Snyder, "One World, Rival Theories," Foreign Policy 145 (2004): 52-62.

41 Teotónio R. de Souza, "Machiavelli, A Modern European Avatar of Kautilya," 2011, https://www.semanticscholar.org/ paper/Machiavelli\%2C-a-Modern-European-Avatar-of-Kautilya-Souza/b51d9e73d8b14bad3ba1cda38600c9108cec9880; Amitav Acharya, "Global International Relations (IR) and Regional Worlds: A New Agenda for International Studies," International Studies Quarterly 58, no. 4 (2014): 647-59

42 Deepshikha Shahi, Kautilya and Non-Western IR Theory (Cham: Palgrave Macmillan, 2018).

43 Pieczara, "Two Modes of Dialogue".

44 Michael Liebig, "Statecraft and Intelligence Analysis in the Kautilya-Arthashastra," Journal of Defence Studies 8, no. 4 (2014): 29 


\subsection{Language vs. concept}

As of now, the tactic of 'provincializing' has been seen as a remedy to the problem of Eurocentrism in IR. However, the ideas/concepts/methods/theories originating from the 'non-Western provinces' are many a time recognized merely as 'linguistic', not 'conceptual', additions to the already existing body of Eurocentric IR knowledge. In other words, the supplementary influx of Chinese, African, Indian or Arabic linguistic terms is hailed as a sufficient proof of the enhanced 'globality' of IR; it is barely assessed if this enhanced globality (resulting from the influx of alien terminologies) is capable of offering novel concepts to deal with the challenges of contemporary global politics. In a way, it is presumed that the Eurocentric IR knowledge 'knows it all'; what non-Eurocentric IR knowledge could do is to inclusively participate in 'politics of knowledge' which, in turn, would lead to the awakening of non-Western linguistic resources to offer a 'derivative discourse' (or conceptual imitation/ replication) of the same Eurocentric IR knowledge, thereby manufacturing nothing more than 'analogies'. Although the Western curiosity surrounding the non-Western linguistic additions (or 'analogies') is appreciable, ${ }^{45}$ an effective West-non-West dialogue requires a different kind of intellectual temperament: such an intellectual temperament not only presupposes that the same concept can possess different meanings in different milieus ${ }^{46}$ but also confesses that there are different concepts (in both Western and non-Western traditions) that presently remain denigrated and, therefore, prohibited from the mainstream Eurocentric IR knowledge. ${ }^{47}$ As such, the entrance of a non-Western 'vocabulary' to IR knowledge is not essentially about 'linguistics'; it could also be about 'concepts': even if these non-Western concepts presently remain at the outskirts of formal IR knowledge, they, nonetheless, continually affect the mind-set of various actors who keenly shape the realities of today's IR.

\subsection{Culture vs. economy}

Similar to the trend of delimiting non-Western IR knowledge to 'language' (not 'concept'), there is an obvious propensity to compartmentalize non-Western IR knowledge as 'cultural' (or 'spiritual'), not 'economic' (or 'material'). Arlene B. Tickner writes:48

[The] non-Western experiences with nationalism have been premised upon opposition and difference to imported models. However, Partha Chatterjee [1986] explains that anticolonial nationalism in the African and Asian contexts is also characterised by a fundamental contradiction entailing imitation and rejection vis-à-vis modernity and tradition. At the same time that the bearer of modernity, the colonial power, is to be rejected, it is also to be imitated by way of its 'universal' methods; similarly, traditional practices considered to pose an obstacle to progress are rejected, while they are also revered as the bearers of national identity. In consequence, such [non-Western] experiences... are characterised by a dual process consisting of: (1) replication and emulation of those material practices (law, statecraft, economy, etc.) imposed by the coloniser, in order to erase difference; and (2) careful guarding of spiritual practices, where cultural identity resides, in order to preserve cultural distinctiveness.

${ }^{45}$ Dirk Messner, During a formal discussion at the international conference on Futures of Global Cooperation (Centre for Global Cooperation Research, University of Duisburg-Essen, Germany, 8-10 November, 2017).

46 Rösch and Watanabe, "Approaching the Unsynthesizable".

47 Deepshikha Shahi and Gennaro Ascione, "Rethinking the Absence of post-Western International Relations Theory in India: 'Advaitic Monism' as an Alternative Epistemological Resource," European Journal of International Relations 22, no. 2 (2016): 313-34.

${ }^{48}$ Arlene B. Tickner, "Seeing IR Differently: Notes from the Third World," Millennium: Journal of International tudies 32, no. 2 (2003): 322 . 
This stereotypical post-colonial/de-colonial way of putting the 'cultural/spiritual' and 'economic/material' domains in separate boxes (which, in turn, implies preventing the nonWestern experiences from uniformly intervening in both the boxes) is highly detrimental to an effective West-non-West dialogue, ${ }^{49}$ especially in the era of Global IR which witnesses both the 'culturalization of the economic' and 'economization of the culture'. ${ }^{50}$ As Global IR - specifically after 2008 global financial crisis - confronts the 'economy as a cultural system,' the economic undertones of non-Western cultural voices must be readily affirmed and proactively incorporated in the dialogic approach to Global IR. ${ }^{51}$

\title{
4.5. Single vs. plural
}

As global dialogues deal with divergent Western and non-Western voices while making efforts to resolve different sorts of political-economic-cultural-crises within the prevailing neoliberal world order, they inevitably face a core unresolved tension: that is, the tension between 'single' (read 'universal') and 'plural' (read 'particular'). Friedrich V. Kratochwil illustrates: ${ }^{52}$

[Q]uite different from the philosophical argument that we are part of just another episode of the [single] relentless historical process leading to ever more inclusive forms of political organization, the spread of universalism [by Eurocentric IR] is strongly counteracted by the equally strong assertion of particularities [or non-assimilative pluralities by non-Eurocentric post-colonial and de-coloinal IR]. Precisely because the packed imagery of the visionary global culture [involving the conceptualisations, mechansisms, and policies of 'dialogue' in Eurocentric IR] is either trivial or shallow.

This 'single vs. plural'/'universal vs. particular' tension - that unrelentingly circumvents the dialogic approach to Global IR - provokes an intellectual tussle between 'Eurocentric IR' and 'non-Eurocentric post-colonial and de-colonial IR'. Deepshikha Shahi simplifies: ${ }^{53}$

\begin{abstract}
In an effort to challenge the universalist claims of Eurocentric IR, the non-Eurocentric postcolonial and de-colonial IR present a holist view of reality: a holist view that emphasizes upon combining the 'missing particularist narratives of/from the non-Western parts' with the 'provincialized particularist narratives of/from the Western parts' for seizing the whole/holist reality of IR. However, this holist view of reality presented by post-colonial and de-colonial IR recommends the same Eurocentric dualism: while Eurocentric IR maintains the separation between the West and the Rest, the non-Eurocentric post-colonial and de-colonial IR reverse this knowledge-situation and retain the separation between the Rest and the West.
\end{abstract}

While the West claims universality and, therefore, conveniently confines the non-West to a 'local' domain, the non-West too eagerly appropriates for itself the 'local' domain as a reaction against the West's arrogant claim to universality. ${ }^{54}$ However, this reactionary

49 Contrary to the post-colonial compartmentalization of 'materialism/economy' and 'spiritualism/culture', Ghanshyam Shah (2013) offers a re-reading of Gandhi's famous work Hind Swaraj (originally published in 1909) to reveal how the elements of both spiritualism and materialism are mutually enmeshed in the philosophical schools of not only the the West, but also the non-West (including India). Ghanshyam Shah, Re-reading Hind Swaraj : Modernity and Subalterns (New Delhi: Routledge, 2013).

${ }_{50}$ William Biebuyck and Judith Meltzer, "Cultural Political Economy," in Oxford Research Encyclopedia of International Studies (Oxford: Oxford University Press, 2010).

51 Todd Dufresne and Clara Sacchetti, eds, The Economy as Cultural System: Theory, Capitalism, Crisis (New York: Bloomsbury, 2012)

${ }_{52}$ Friedrich V. Kratochwil, "Politics, Norms and Peaceful Change," Review of International Studies (The Eighty Years' Crisis 1919-1999) 24 (1998): 215

53 Shahi, Advaita, 110-11.

${ }^{54}$ In this context, it is relevant to recall the role of International Studies Association (ISA) which, in its bid to manufacture 'global dialogues' in IR, often invites and arranges the voices from the non-West ('local' domains) along 'all women' or 'all young' or 'all non-white' discursive panels: rather than boxing these non-Western voices along particular gender, age or racial grounds, it 
reduction of non-Western intellectual projects into a 'regional' discourse applicable only to a 'local' domain is exceedingly problematic: in fact, a few post-Western intellectual projects (e.g. the ones inspired by non-Western philosophies of Sufism, Advaita etc.) generate a 'universalist' discourse that is capable of explaining/describing the general realities of international relations (as applicable to the entire Globe), without suppressing the 'particularist' realities of international relations (as applicable to a 'local' domain). Thus, whenever 'single vs. plural'/'universal vs. particular' tension disrupts an effective Westnon-West dialogue, one needs to make the following twofold observation: (i) the West does not exhaust the universalist explanations/descriptions of international relations; in fact, the non-West does (and can) add to the universalist explanations/descriptions of international relations; (ii) the dialogic approach to Global IR must not compulsorily subscribe to 'universal vs. particular' or 'single vs. plural' tension; 55 it could, rather, transcend this tension by inculcating an intellectual attitude that upholds 'universal along with particular' or 'single along with plural'.

\section{Concluding Remarks}

Principally, the complexities of a dialogic approach to Global IR are offshoots of a broader 'politics of knowledge'. As the pioneer of this politics of knowledge, the West had selfassigned a 'white-man's burden' which, in turn, eventually manifested into its legitimized role as a conventional knowledge-producer in IR (and other social sciences). On the flip side, this meant not only the subjugation of the non-West as a valid knowledge-producer, but also the allocation to the non-West the fixed role of a knowledge-consumer. For a prolonged period, both the West and the non-West (un)critically moved ahead with this status-quoist 'knowledgepower equations'. However, lately, both the West and the non-West have deliberately entered into a polemical mode which allows an unprecedented opening to heterodox IR theorizations stirred by alien knowledge-forms. In fact, this opening to heterodox IR theorizations is motivated by the need to pursue the 'Global': the main challenge facing contemporary IR is how to make it Global by extending its theoretical-practical grounds beyond Eurocentric biases. And one of the most treaded pathways to address these Eurocentric biases has been the inclusion of non-Western worldviews. But it is pertinent to bear in mind that the greater inclusion of non-Western worldviews - for instance, the incorporation of Chinese, Indian, or Brazilian voices in global dialogues - cannot make IR less Eurocentric or more Global if the following slippery slopes are ignored: (i) if non-Western voices nurture a 'derivative discourse' of the same Western IR (e.g. if Kautilya's Arthaśāstra is uttered as the Indian version of the same Western Realism); (ii) if non-Western voices foster an 'exceptionalist discourse' which is narrowly applicable to the experiential realities of a native time-space zone (e.g. the post-colonial and de-colonial debates that sanction a rigid division between the particularist politico-experiential realities of the colonizing and colonialized worlds).

would be more helpful if these voices are aligned on the basis of their universally applicable conceptual merits.

55 Eurocentric IR compulsorily subscribes to 'universal vs. particular' tension as its dualist frameworks presume that there cannot be a 'non-perspectival perspective'. (Richard Shapcott, Justice, Community and Dialogue in International Relations (Cambridge: Cambridge University Press, 2001)). For instance, Iris M. Young argues: 'It is impossible to adopt an unsituated moral [or theoretical] point of view. And if a point is situated, then it cannot be universal...hence, [all universal accounts of realities provide] monological [not dialogical] accounts of human agency'. Iris M. Young, Justice and the Politics of Difference (Princeton: Princeton University Press, 1990), 104. By contrast, the origins or applications of Sufi non-Eurocentric IR cannot be strictly tied down to specific spatio-temporal locations/centers of situated knowledge-forms. For a detailed discussion on this issue, see Deepshikha Shahi, "Introducing Sufism to International Relations Theory: A Preliminary Inquiry into Epistemological, Ontological, 
Although the politics of knowledge was imposed by the West on the non-West in a binary fashion, a conscientious pursuit of Global IR today calls for a fresh politics of knowledge wherein an effective West-non-West dialogue cautiously plays out on non-binary, or say nonretaliatory, terms and conditions.

\section{Bibliography}

Acharya, Amitav. "Dialogue and Discovery: In Search of International Relations Theories Beyond the West." Millennium: Journal of International Studies 39, no. 3 (2011): 619-37.

—. "Global International Relations (IR) and Regional Worlds: A New Agenda for International Studies." International Studies Quarterly 58, no. 4 (2014): 647-59.

Acharya, Amitav, and Barry Buzan. The Making of Global International Relations. Cambridge: Cambridge University Press, 2019.

Alker, Hayward R. "The Dialectical Logic of Thucydides' Melian Dialogue." The American Political Science Review 82, no. 3 (1988): 805-20.

Anievas, Alexander. "On Habermas, Marx and the Critical Theory Tradition: Theoretical Mastery or Drift?" In International Relations Theory and Philosophy: Interpretive Dialogues, edited by C. Moore and C. Farrands, 144-56. London: Routledge, 2010.

Balci. Ali. "Knowledge, Repetition and Power in Ibn al-'Arabi's Thought: Some Preliminary Comments on Methodology." All Azimuth 4, no. 1 (2015): 39-50.

Banchoff, Thomas. "Religion and the Global Politics of Human Dignity." In Human Dignity and the Future of Global Institutions, edited by Mark P. Lagon and Anthony Clark Arend, 257-76. Georgetown: Georgetown University Press, 2014.

Behr, Hartmut, and Michael C. Williams. "Interlocuting Classical Realism and Critical Theory: Negotiating 'Divides' in International Relations Theory.” Journal of International Political Theory 13, no. 1 (2017): 3-17.

Bhambra, Gurminder K. "Talking Among Themselves? Weberian and Marxist Historical Sociologies as Dialogues Without 'Others'.” Millennium: Journal of International Studies 39, no. 3 (2011): 667-81.

Biebuyck, William, and Judith Meltzer. "Cultural Political Economy." In Oxford Research Encyclopedia of International Studies. Oxford: Oxford University Press, 2010.

Biersteker, Thomas J. “Eroding Boundaries, Contested Terrain.” International Studies Review 1 (1999): 3-9.

Blanshard, Brand. The Nature of Thought (2 volumes). London: George Allen and Unwin Ltd, 1939.

Bohm, David. On Dialogue. London: Routledge, 1996.

Capan, Zeynep G. “Decolonising International Relations?” Third World Quarterly 38, no. 1 (2017): 1-15.

Chatterjee, Partha. Nationalist Thought and the Colonial World: A Derivative Discourse. London: Zed Books, 1986. Curtis, Simon, and Marjo Koivisto. "Towards a Second 'Second Debate'? Rethinking the Relationship between Science and History in International Theory.” International Relations 24, no. 4 (2010): 433-55.

Der Derian, James. Critical Practices in International Theory: Selected Essays. London and New York: Routledge, 2009.

de Souza, Teotónio R. "Machiavelli, A Modern European Avatar of Kautilya.” 2011. https://www.semanticscholar. org/paper/Machiavelli\%2C-a-Modern-European-Avatar-of-Kautilya-Souza/b51d9e73d8b14bad3ba1cda38600 c9108cec9880.

Diez, Thomas, and Jill Steans. "A Useful Dialogue? Habermas and International Relations.” Review of International Studies 31 (2005): 127-40.

Dufresne, Todd, and Clara Sacchetti, eds. The Economy as Cultural System: Theory, Capitalism, Crisis. New York: Bloomsbury, 2012.

Eun, Yong-Soo. "Beyond 'the West/non-West Divide' in IR: How to Ensure Dialogue as Mutual Learning." The Chinese Journal of International Politics 11, no. 4 (2018): 435-49. 
Grovogui, Siba N. Beyond Eurocentrism and Anarchy: Memories of International Order and Institutions. New York, NY: Palgrave Macmillan, 2006.

Guillaume, Xavier. "Bakhtin: From Substance to Process." In International Relations Theory and Philosophy: Interpretive Dialogues, edited by C. Moore and C. Farrands. London and New York: Routledge, 2010.

Harpaz, Guy. "The Role of Dialogue in Reflecting and Constituting International Relations: The Causes and Consequences of a Deficient European-Israeli Dialogue.” Review of International Studies 37, no. 4 (2011): $1857-83$.

Hellmann, Gunther. “Are Dialogue and Synthesis Possible in International Relations?” International Studies Review 5, no. 1 (2003): 123-50.

Hermann, Margaret G. "One Field, Many Perspectives: Building the Foundations for Dialogue." International Studies Quarterly 42 (1998): 605-24.

Hobson, John M. "East and West in Global History." Theory, Culture \& Society 23, no. 2-3 (2006): 408-10.

—. The Eastern Origins of Western Civilisation. Cambridge: Cambridge University Press, 2004.

Hobson, John M., and Alina Sajed. "Navigating Beyond the Eurofetishist Frontier of Critical IR Theory: Exploring the Complex Landscapes of Non-Western Agency.” International Studies Review 19, no. 4 (2017): 547-72.

Hutchings, Kimberly. "Dialogue between Whom? The Role of the West/ Non-West Distinction in Promoting Global Dialogue in IR.” Millennium: Journal of International Studies 39, no. 3 (2011): 639-47.

Jones, Branwen G. ed. Decolonizing International Relations. Lanham: Rowman \& Littlefield, 2006.

Kayaoglu, Turan. "Westphalian Eurocentrism in International Relations Theory." International Studies Review 12, no. 2 (2010): 193-217.

Köchler, Hans, and Gudrun Grabher, eds. Civilizations - Conflict or Dialogue?. Vienna: International Progress Organization, 1999.

Korab-Karpowicz, Włodzimierz J. "How International Relations Theorists Can Benefit by Reading Thucydides." The Monist 89, no. 2 (2006): 232-44.

Kratochwil, Friedrich V. "Politics, Norms and Peaceful Change." Review of International Studies (The Eighty Years' Crisis 1919-1999) 24 (1998): 193-218.

- The Puzzles of Politics: Inquiries into the Genesis and Transformation of International Relations. New York: Routledge, 2010.

Kristensen, Peter M. "International relations in China and Europe: The Case for Interregional Dialogue in a Hegemonic Discipline.” The Pacific Review 28, no. 2 (2014): 161-87.

Lacatus, Cora, Daniel Schade, and Yuan Yao. "Quo vadis IR: Method, Methodology and Innovation.” Millennium: Journal of International Studies 43, no. 3 (2015): 767-78.

Lapid, Yosef. “Through Dialogue to Engaged Pluralism: The Unfinished Business of the Third Debate.” International Studies Review 5, no. 1 (2003): 128-31.

Liebig, Michael. "Statecraft and Intelligence Analysis in the Kautilya-Arthashastra." Journal of Defence Studies 8, no. 4 (2014): 27-54.

Linklater, Andrew. "The Changing Contours of Critical International Relations Theory." In Critical Theory and World Politics, edited by Richard Wyn Jones. London: Lynne Reinner Publishers, 2001.

Lovejoy, Arthur O. The Revolt Against Dualism. Chicago: Open Ccourt Publishing, 1930.

Malmvig, Helle. "Security through Intercultural Dialogue? Implications of the Securitization of Euro-Mediterranean Dialogue between Cultures.” Mediterranean Politics 10, no. 3 (2005): 349-64.

Messner, Dirk. During a formal discussion at the international conference on Futures of Global Cooperation. Centre for Global Cooperation Research, University of Duisburg-Essen, Germany, 8-10 November, 2017.

Mignolo, Walter D. The Darker Side of Western Modernity: Global Futures, Decolonial Options. Durham and London: Duke University Press, 2011.

Moravcsik, Andrew. "Theory Synthesis in International Relations: Real Not Metaphysical." International Studies Review 5, no. 1 (2003): 131-36. 
Muller, Harald. "Arguing, Bargainig and All That: Communicative Action, Rationalist Theory and the Logic of Appropriateness in International Relations.” European Journal of International Relations 10, no. 3 (2004): 395-435.

Neumann, Iver B. “International Relations as Emergent Bakhtinian Dialogue.” International Studies Review 5, no. 1 (2003): $137-40$.

Paolini, Albert J. Navigating Modernity: Postcolonialism, Identity, and International Relations. London: Lynne Rienner Publishers, 1999.

Parfit, Derek. Reasons and Persons. Oxford: Oxford University Press, 1984.

Pieczara, Kamila. "Two Modes of Dialogue in IR : Testing on Western versus Non-Western Engagement with IR Theory." Millennium Annual Conference, London School of Economics (2010): 1-17.

Rösch, Felix, and Atsuko Watanabe. "Approaching the Unsynthesizable in International Politics: Giving Substance to Security Discourses through Basso Ostinato?” European Journal of International Relations 23, no. 3 (2016): 609-29.

Rosenau, James N. Global Voices: Dialogues in International Relations. Boulder: Westview Press, 1993.

Sabaratnam, Meera. "IR in Dialogue. But Can We Change the Subjects? ATypology of Decolonising Strategies for the Study of World Politics.” Millennium: Journal of International Studies 39, no. 3 (2011): 781-803.

Schmidt, Brian C. "A Realist View of the Eurocentric Conception of World Politics." Millennium:Journal of International Studies 42, no. 2 (2014): 464-71.

Shah, Ghanshyam. Re-reading Hind Swaraj : Modernity and Subalterns. New Delhi: Routledge, 2013.

Shahi, Deepshikha. Advaita as a Global International Relations Theory. London and New York: Routledge, 2018.

__. "Introducing Sufism to International Relations Theory: A Preliminary Inquiry into Epistemological, Ontological, and Methodological Pathways." European Journal of International Relations 25, no. 1 (2018): 250-75.

—. Kautilya and Non-Western IR Theory. Cham: Palgrave Macmillan, 2018.

Shahi, Deepshikha, and Gennaro Ascione. "Rethinking the Absence of post-Western International Relations Theory in India: 'Advaitic Monism' as an Alternative Epistemological Resource.” European Journal of International Relations 22, no. 2 (2016): 313-34.

Shapcott, Richard. Justice, Community and Dialogue in International Relations. Cambridge: Cambridge University Press, 2001.

Shimizu, Kosuke. "The Genealogy of Culturalist International Relations in Japan and Its Implications for PostWestern Discourse.” All Azimuth 7, no. 1 (2018): 121-36.

Sil, Rudra, and, Peter Katzenstein. "Analytic Eclecticism in the Study of World Politics: Reconfiguring Problems and Mechanisms across Research Traditions.” Perspectives on Politics 8, no. 2 (2010): 411-31.

Snyder, Jack. “One World, Rival Theories.” Foreign Policy 145 (2004): 52-62.

Sprinz, Detlef F., and Yael Wolinsky-Nahmias. Cases, Numbers, Models: International Relations Research Methods. Michigan: University of Michigan Press, 2002.

Tickner, Arlene B. Seeing IR Differently: Notes from the Third World. Millennium: Journal of International Studies 32, no. 2 (2003): 295-324.

Tickner, Arlene B., and David L. Blaney. Claiming the International. New York: Routledge, 2013.

Tickner, Judith A. "Dealing with Difference: Problems and Possibilities for Dialogue in International Relations." Millennium: Journal of International Studies 39, no. 3 (2013): 607-18.

Tieku, Thomas K. "Collectivist Worldview: Its Challenge to International Relations." In Africa and International Relations in the Twenty-First Century, edited by Fantu Cheru, Timothy Shaw, and Scarlett Cornelissen. Basingstoke: Palgrave Macmillan, 2012.

Tingyang, Zhao. "Rethinking Empire from a Chinese Concept 'All-under-Heaven'." Social Identities 12, no. 1 (2006): 29-41.

Tuna, Agnes. "Intercultural Dialogue: Only a Means, Not an End in Itself. New-Med Research Network", 2016. https://www.osce.org/networks/newmedtrackII/292946?download=true 
Wæver, Ole. "The Sociology of a Not so International Discipline.” International Organization 52, no. 4 (1998): $687-727$.

Williams, Bernard. Problems of the Self: Philosophical Papers 1956-1972. Cambridge: Cambridge University Press, 1973.

Young, Iris M. Justice and the Politics of Difference. Princeton: Princeton University Press, 1990.

Žižek, Slavoj. "The Most Sublime of Hysterics: Hegel with Lacan.” 2006. http://www.lacan.com/zizlacan2.htm. 